\title{
Indole-positive Vibrio vulnificus isolated from disease outbreaks on a Danish eel farm
}

\author{
Inger Dalsgaard ${ }^{1, *}$, Lise Høi $^{2}$, Ronald J. Siebeling ${ }^{3}$, Anders Dalsgaard ${ }^{2}$ \\ 'Danish Institute for Fisheries Research, Fish Disease Laboratory, The Royal Veterinary and Agricultural University, \\ Bülowsvej 13, DK-1870 Frederiksberg C, Denmark \\ ${ }^{2}$ Department of Veterinary Microbiology, The Royal Veterinary and Agricultural University, DK-1870 Frederiksberg C, Denmark \\ ${ }^{3}$ Department of Biological Sciences, Louisiana State University, Baton Rouge, Louisiana, USA
}

\begin{abstract}
Vibrio vulnificus was isolated in 1996 from 2 disease outbreaks on a Danish eel farm which used brackish water. A characteristic clinical sign was extensive, deep muscle necrosis in the head region. $V$. vulnificus was isolated from kidney, mucus, spleen, gill and intestine of diseased eels. Thirty-two isolates were examined phenotypically and serologically for pathogenicity to eels and for correlation to ribotype and plasmid profile. Biochemically, the isolates showed properties similar to those described previously for eel-pathogenic strains of $V$. vulnificus, with the exception of indole production. Virulence was evaluated by $\mathrm{LD}_{50}$ (the $50 \%$ lethal dose), which ranged from $<9.4 \times 10^{3}$ to $2.3 \times$ $10^{5} \mathrm{CFU}$ (colony-forming units) per fish. The isolates which were lethal for eels showed identical ribotypes and serotypes. A relationship between certain plasmids and virulence was not found. A serotyping system based on lipopolysaccharide (LPS)-associated $O$ antigen type and on carbohydrate capsule antigens showed that the eel-virulent isolates shared a common LPS-based homogeneous $O$ serogroup and a capsule antigen. $V$. vulnificus serovar $O 4$ and capsule type 9 was identical serologically to the Japanese isolate ATCC 33149 and was the agent responsible for the disease outbreaks that occurred on the Danish eel farm. Despite absence of antibiotic resistance, treatment had little effect and disease reoccurred.
\end{abstract}

KEY WORDS: Vibrio vulnificus $\cdot$ Fish pathogen $\cdot$ Identification · Virulence

\section{INTRODUCTION}

Eel production in Denmark depends upon import of elvers Anguilla anguilla from France and the United Kingdom. Farming practices have revealed that eels produced in recirculation systems are susceptible to disease outbreaks caused by Vibrio spp. which are not expected to occur when eels are reared in freshwater. However, Vibrio anguillarum infections occur following prophylactic treatment of elvers with salt (Mellergaard \& Dalsgaard 1987). Vibrio vulnificus has been associated with infectious disease in Japanese eel (Muroga et al. 1976) and European eel in Spain, Sweden and Norway (Biosca et al. 1991, 1997a). In addition, $V$. vulnificus has been described as an impor-

•E-mail: inger.dalsgaard@vetmi.kvl.dk tant pathogen that may cause wound infections and fatal septicemia in humans (Oliver 1989).

Vibrio vulnificus has been divided into 2 biotypes which differ phenotypically, serologically, and with respect to host range (Tison et al. 1982). The main phenotypic characteristics that originally differentiated biotype 1 from biotype 2 are indole production, ornithine decarboxylation, growth at $42^{\circ} \mathrm{C}$ and acid production from mannitol (Tison et al. 1982). Most strains isolated from human infections and environmental sources were described as indole positive and belong to biotype 1 , whereas strains recovered from diseased eels were indole-negative and classified as biotype 2 . Amaro et al. (1992b) suggested that biotype 2 isolates, independent of origin, belong to the same serotype, as they exhibit the same lipopolysaccharide (LPS) profile. It has been proposed that those strains previously classified as biotype 2 be classified as serovar E (Biosca 
et al. 1997a). Serovar E comprises the strains of the species which are pathogenic for eels (Biosca et al. 1996). By contrast Amaro et al. (1992b) found a seroheterogeneity among biotype 1 isolates. Research suggests that subtyping of $V$. vulnificus isolates should be based on serological properties and host range, since biochemical traits may vary (Biosca et al. 1997a). Furthermore, biotype 2 has also been reported as an opportunistic pathogen for humans (Veenstra et al. 1992, Amaro \& Biosca 1996).

The majority of eel farms in Denmark use freshwater to culture eels. When located near the coast, Danish eel farms prefer to utilize brackish water. Eels cultured in brackish water exhibit higher growth rates compared to eels cultured in freshwater. However, brackish water can serve as a reservoir for Vibrio vulnificus and might facilite the spread of $V$. vulnificus among eels (Hoi et al. 1998). Growth of $V$. vulnificus can occur in eel farms using brackish water and a water temperature of $24^{\circ} \mathrm{C}$, since these conditions favour growth of this organism (O'Neill et al. 1992).

It has been suggested that the capsule in biotype 2 (serovar E) facilitates initial adherence to eel mucus and is essential for virulence in natural conditions (Amaro et al. 1995). Several capsular serotypes have been reported (Simonson \& Siebeling 1993). The O LPS side chain of serovar $E$ has been shown to protect Vibrio vulnificus biotype 2 against the bacteriocidal action of eel serum complement, whereas biotype 1 strains are readily lysed by eel serum (Amaro et al. 1997). In addition, high molecular weight plasmids, when present in serovar E strains, may influence virulence (Biosca et al. 1997a).

This investigation presents recurrent disease outbreaks of Vibrio vulnificus on a Danish eel farm. The clinical manifestations of diseased eels are described and isolates characterized phenotypically and genetically. Polyclonal antisera to 10 capsular types and monoclonal antibodies to 5 LPS serotypes (Martin \& Siebeling 1991, Simonson \& Siebeling 1993) were used to serologically characterize $V$. vulnificus isolates recovered from diseased eels. Finally, the pathogenicity of the isolates was evaluated.

\section{MATERIALS AND METHODS}

Bacterial strains. A total of 32 isolates were isolated from an eel farm during 2 disease outbreaks in 1996. The eels were reared in brackish water with a salinity of $0.9 \%$ and a temperature of $24^{\circ} \mathrm{C}$. Samples were collected aseptically from the kidney and spleen and streaked onto blood agar plates (BA: Blood Agar base [Difco] with $5 \%$ citrated calf blood) and incubated at $20^{\circ} \mathrm{C}$ for 48 to $96 \mathrm{~h}$. Six eels were examined from the first outbreak and 7 from the second outbreak. In addition to our routine diagnostic work, approximately $1 \mathrm{~g}$ each of mucus, gill tissue and intestinal content was pre-enriched in alkaline peptone water $(\mathrm{pH} 8.6,1 \%$ $\mathrm{NaCl}$ ) at $37^{\circ} \mathrm{C}$ for 6 to $8 \mathrm{~h}$, and $1 \mu \mathrm{l}$ of the preenrichment was streaked onto modified cellobiosepolymyxin B-colistin ( $\mathrm{mCPC}$ ) agar and incubated at $40^{\circ} \mathrm{C}$ for 18 to $24 \mathrm{~h}$ (Høi et al. 1998). Putative Vibrio vulnificus colonies (yellow, flat, 2 to $3 \mathrm{~mm}$ diameter) were subcultured on BA.

Reference strains of Vibrio vulnificus biotype 1 (ATCC 27562), and biotype 2 (ATCC 33149) and 4 biotype 2 strains isolated from diseased eels in Spain, Norway and Sweden were included (Table 1).

Colony hybridization. Colony blots were made from suspected Vibrio vulnificus grown on BA for 18 to $24 \mathrm{~h}$ at $37^{\circ} \mathrm{C}$ as described by Høi et al. (1998). The alkaline phosphatase-labelled oligonucleotide (VVAP) probe (DNA Technology, Aarhus, Denmark) used to identify $V$, vulnificus was: GAGCTGTCACGGCAGTTGGAACCA (Wright et al. 1993). Filters, including positive and negative controls, were pre-hybridized and hybridized at high stringency $\left(56^{\circ} \mathrm{C}\right)$ and developed by methods described previously (Wright et al. 1993, Høi et al. 1998).

Phenotypic characterization. Vibrio vulnificus isolates were characterized by the following selected criteria: Gram stain, oxidase, catalase, motility, arginine dihydrolase, lysine decarboxylase, and ornithine decarboxylase, sensitivity to $\mathrm{O} / 129$, mannitol, salicin, cellobiose, ONPG (o-nitrophenyl- $\beta$-D-galactopyranoside), indole, Voges-Proskauer, TCBS (thiosulphate citrate bile salt sucrose), and growth in $0 \%, 6 \%, 7 \%, 10 \%$ $\mathrm{NaCl}$ and at $42^{\circ} \mathrm{C}$. The methods were as described by Barrow \& Feltham (1993). Unless otherwise indicated each substrate contained $1 \% \mathrm{NaCl}$ and was incubated at $37^{\circ} \mathrm{C}$.

Whole-cell ELISA. Five LPS-specific monoclonal antibody reagents designated 01 to 05 were used in the whole-cell enzyme-linked immunosorbent assay (ELISA) format (Martin \& Siebeling 1991). The Vibrio vulnificus isolates tested by ELISA were grown in heart infusion broth ( $\mathrm{HI}$; Difco) for $24 \mathrm{~h}$ at $37^{\circ} \mathrm{C}$ and then diluted with an equal volume of phosphatebuffered saline $(\mathrm{pH} 7.5)$, which gives $3 \times 10^{9}$ colony forming units (CFU) $\mathrm{ml}^{-1}$. A $50 \mu \mathrm{l}$ aliquot of the diluted cell suspension was added to each well of $2 \times 8$ flat bottom wells of protein-binding polystyrene (Immunlon 1; Dynatech Laboratories, Inc., Alexandria, VA). The cells were dried overnight at $37^{\circ} \mathrm{C}$. The ELISA using antiLPS monoclonal antibody was done as described previously (Martin \& Siebeling 1991). The $A_{405}$ (absorbance of $405 \mathrm{~nm}$ wavelength) for each well was read after 15 min incubation with substrate in a microwell strip reader (Biotek Instruments, Inc., Winooski, VT). A well 
was considered positive if its $A_{405}$ reading was 0.200 above that of a negative control.

Coagglutination. Polyclonal rabbit anti-capsule sera were fixed to formalin-killed Staphylococcus aureus Cowan I ATCC 12598 cells (Simonson \& Siebeling 1986). A single opaque colony of the Vibrio vulnificus isolates was grown in $\mathrm{HI}$ for $24 \mathrm{~h}$ at $30^{\circ} \mathrm{C}$ and tested directly by coagglutination. Capsule purification methods, conjugation of capsule to protein carriers and rabbit immunization protocols have been described earlier (Simonson \& Siebeling 1993). Ten anti-capsule sera were used and each isolate in the present study was tested against each of these antisera. The capsule type described earlier representing $V$. vulnificus strain 938 (Simonson \& Siebeling 1993) has the designation 9 in the present study.

Antibiotic susceptibility. Each isolate was tested for antibiotic susceptibility to 15 antibacterial drugs by disc diffusion on Mueller-Hinton agar (Difco). Antibiotic susceptibility was tested by following the instructions of the manufacturer (Neo-Sensitabs, Rosco Diagnostica, Denmark) and included the following antibiotics ( $\mu \mathrm{g} \mathrm{disc} \mathrm{dic}^{-1}$ ): ampicillin 33, cephalothin 66 , chloramphenicol 60, ciprofloxacin 10, enrofloxacin 10 , erythromycin 78 , gentamycin 40 , neomycin 120 , oxolinic acid 10, penicillin 62.5, polymyxin B 150 , streptomycin 100 , sulphadiazin 240 , tetracycline 10 , trimethoprim/sulfamethoxazole $5.2 / 240$ and the vibriostatic agent $\quad$ /129 (2,4-diamino-6,7-diisopropylpteridine phosphate 150 ). Inhibition zones were read following incubation at $37^{\circ} \mathrm{C}$ overnight. Sensitivity of each strain to each antibiotic was determined according to the manufacturer's instructions (Rosco Diagnostica).

Plasmid analysis and ribotyping. Preparation of plasmid DNA and resolution by electrophoresis were done by methods described by Olsen (1990), which included incubation of the bacterial cells at elevated $\mathrm{pH}$ (12.45) for $30 \mathrm{~min}$ at $56^{\circ} \mathrm{C}$ during the lysis step. The molecular size of each plasmid was estimated by using reference plasmids of known size recovered from Escherichia coli V517 (8 plasmids which ranged from 54 to $2.0 \mathrm{~kb}$ ) (Rochelle et al. 1985) and E. coli 39R 861 (4 plasmids which ranged from 147 to $6.9 \mathrm{~kb}$ ) (Threlfall et al. 1986). Each $V$. vulnificus isolate was screened for plasmids at least twice.

Total bacterial DNA was extracted from each isolate by the method of Pedersen \& Larsen (1993). Based on findings from previous studies, HindIII (Promega, Madison, WI) was selected in the ribotyping (Dalsgaard et al. 1996b, Høi et al. 1997). Ribotyping was done using the procedure described by Dalsgaard et al. (1996a) in which digoxigenin-labelled $16 \mathrm{~S}$ and $23 \mathrm{~S}$ rRNA probes were used. A $1 \mathrm{~kb}$ molecular weight standard (GIBCO BRL, Gaithersburg, MD) was used as a molecular weight marker. Ribotype patterns were considered to be unique if there was a difference of 1 band between each isolate, following which each ribotype was assigned an arbitrary number.

Experimental infection. Eels Anguilla anguilla with a body weight of 10 to $12 \mathrm{~g}$ were used. The fish were kept in 20 l capacity tanks which contained aerated, static freshwater maintained at 23 to $24^{\circ} \mathrm{C}$. The water was changed daily. Cultures of Vibrio vulnificus were grown in Veal Infusion broth (Difco) with $1 \% \mathrm{NaCl}$ overnight at $37^{\circ} \mathrm{C}$ ( 2 isolates were tested both after growth at $37^{\circ} \mathrm{C}$ and at $20^{\circ} \mathrm{C}$ ), centrifuged at $3000 \times g$ for $10 \mathrm{~min}$ and the cell pellets were resuspended in $10 \mathrm{ml}$ volumes of $0.9 \%(\mathrm{w} / \mathrm{v})$ saline to a final concentration of approximately $10^{8}$ cells $\mathrm{ml}^{-1}$. For each $V$. vulnificus isolate, 6 eels were injected intraperitoneally with $0.1 \mathrm{ml}$ of 10 -fold dilutions. Mortalities were recorded daily for 7 d (Amaro et al. 1992a). Kidney and spleen samples collected from dead and moribund fish were cultured on BA. Surviving eels were sacrified at the end of the experiment and examined in a similar manner. Mortalities due to $V$. vulnificus were recorded only if the injected bacterium was recovered in pure culture from tissue samples. For each $V$. vulnificus isolate tested, the $50 \%$ lethal dose ( $\left.\mathrm{LD}_{50}\right)$ was calculated by the method of Reed \& Müench (1938)

\section{RESULTS}

\section{Clinical observations}

Eel mortality occurred on the farm in April 1996 and, in spite of repeated antibacterial treatment with either tetracycline or oxolinic acid, a second outbreak occurred again 3 mo later. The diseased eels were listless and exhibited clinical signs typical of bacterial septicemia, which included external haemorrhaging in the ocular area and in some cases exophthalmia. Erosive lesions developed on the operculum area and in the jaw region. The spleen was enlarged and congested. High mortality and septicemia occurred during the first outbreak, and Vibrio vulnificus was isolated from both external and internal samples collected from the eels. During the second outbreak of clinical disease (3 mo later), the mortality was lower and the head lesions were more severe compared to those seen in the first outbreak. $V$. vulnificus was isolated from the mucus, gills, intestines and spleen, but not from the kidneys (Table 1). Other eel pathogenic bacteria were not isolated during the 2 outbreaks.

\section{Characterization of Vibrio vulnificus}

The isolates exhibited phenotypic characteristics typical of Vibrio vulnificus (Kelly et al. 1991). They grew as 
Table 1. Vibrio vulnificus Source, phenotypic, serological and genotypic characterization of $V$, vulnificus reference strains and $V$. vulnificus associated with 2 disease outbreaks on a Danish eel farm. LPS: Lipopolysaccharide. NT: non-typeable

\begin{tabular}{|c|c|c|c|c|c|}
\hline Strain no. & Source & $\begin{array}{l}\text { Indolet } \\
\text { mannitol }\end{array}$ & $\begin{array}{c}\text { LPS/capsule } \\
\text { serotype }\end{array}$ & $\begin{array}{l}\text { Plasmid } R \\
\text { size }(\mathrm{kb})\end{array}$ & $\begin{array}{l}\text { Ribotype } \\
\text { (HindIII) }\end{array}$ \\
\hline ATCC 27562 & Human blood, USA & $+1+$ & $1 / \mathrm{NT}$ & $--^{a}$ & 1 \\
\hline ATCC 33149 & Diseased eel, Japan & $-1-$ & $4 / 9$ & 56,67 & 3 \\
\hline $\mathrm{E} 22^{\mathrm{b}}$ & Diseased eel, Spain & $-1-$ & $4 / 9$ & 56,67 & 3 \\
\hline $90-2-11^{c}$ & Diseasd eel, Norway & $-1-$ & $4 / 9$ & 56,71 & 3 \\
\hline$\dddot{O} 120^{d}$ & Diseased eel, Sweden & $-1-$ & $4 / 9$ & 51,71 & 3 \\
\hline $938^{\mathrm{e}}$ & Diseased eel, Norway & $y-1-$ & $4 / 9$ & 56,71 & 3 \\
\hline \multicolumn{6}{|c|}{ Strains isolated from the first outbreak } \\
\hline $960426-1 / 4 A$ & Mucus & $+1-$ & $4 / 9$ & $40,63,105$ & 3 \\
\hline $960426-1 / 4 \mathrm{~B}$ & Intestine & $+1-$ & $4 / 9$ & $40,63,105$ & 3 \\
\hline $960426-1 / 4 C$ & Kidney & $+1-$ & $4 / 9$ & $40,63,105$ & 3 \\
\hline $960426-1 / 4 D$ & Spleen & $+1-$ & $4 / 9$ & $40,63,105$ & 3 \\
\hline $960426-1 / 6 \mathrm{~A}$ & Mucus & $+1-$ & $4 / 9$ & $40,63,105$ & 3 \\
\hline $960426-1 / 6 \mathrm{~B}$ & Gills & $+1-$ & $4 / 9$ & $40,63,105$ & 3 \\
\hline $960426-1 / 6 \mathrm{C}$ & Kidney & $+1-$ & $4 / 9$ & $40,63,105$ & 3 \\
\hline $960426-1 / 6 \mathrm{D}$ & Spleen & $+1-$ & $4 / 9$ & $40,63,105$ & 3 \\
\hline $960426-1 / 6 \mathrm{E}$ & Kidney & $+1-$ & $4 / 9$ & $40,63,105$ & 3 \\
\hline $960426-1 / 6 F$ & Spleen & $+/-$ & $4 / 9$ & $40,63,105$ & 3 \\
\hline $960426-1 / 6 \mathrm{G}$ & Kidney & $+1-$ & $4 / 9$ & $40,63,105$ & 3 \\
\hline $960426-1 / 6 \mathrm{H}$ & Spleen & $+1-$ & $4 / 9$ & $40,63,105$ & 3 \\
\hline \multicolumn{6}{|c|}{ Strains isolated from the second outbreak } \\
\hline $960717-1 / 1 C$ & Gills & $+1-$ & $4 / 9$ & 63 & 3 \\
\hline $960717-1 / 1 \mathrm{D}$ & Mucus & $+/ t$ & NT & 105,135 & 4 \\
\hline $960717-1 / 2 \mathrm{~A}$ & Gills & $+1-$ & $4 / 9$ & 63 & 3 \\
\hline $960717-1 / 2 C$ & Mucus & $+1-$ & $4 / 9$ & 63 & 3 \\
\hline $960717-1 / 2 \mathrm{D}$ & Mucus & $+1+$ & NT & 135 & 4 \\
\hline $960717-1 / 2 \mathrm{E}$ & Intestine & $+1+$ & NT & 135 & 4 \\
\hline $960717-1 / 2 \mathrm{~F}$ & Spleen & $+1-$ & $4 / 9$ & $40,63,105$ & 3 \\
\hline $960717-1 / 3 A$ & Gills & $+/-$ & $4 / 9$ & $40,63,105$ & 3 \\
\hline $960717-1 / 3 B$ & Gills & $+/+$ & NT & 135 & 4 \\
\hline $960717-1 / 3 C$ & Intestine & $+1+$ & NT & 105 & 4 \\
\hline $960717-1 / 4 \mathrm{~A}$ & Intestine & $+/+$ & NT & 135 & 4 \\
\hline $960717-1 / 4 \mathrm{~B}$ & Spleen & $+/ t$ & NT & 135 & 4 \\
\hline $960717-1 / 4 C$ & Mucus & $+/+$ & NT & 135 & 4 \\
\hline $960717-1 / 5 \mathrm{~A}$ & Gills & $+1-$ & $4 / 9$ & 105 & 3 \\
\hline $960717-1 / 5 \mathrm{~B}$ & Mucus & $+1-$ & $4 / 9$ & $40,63,105$ & 3 \\
\hline $960717-1 / 5 \mathrm{C}$ & Intestine & $+/ t$ & NT & 135 & 4 \\
\hline $960717-1 / 6 \mathrm{~A}$ & Gills & $+1=$ & $4 / 9$ & $40,63,105$ & 3 \\
\hline $960717-1 / 6 \mathrm{C}$ & Mucus & $+1+$ & NT & 105 & 4 \\
\hline $960717-1 / 7 \mathrm{E}$ & Mucus & $+1+$ & NT/9 & 135 & 4 \\
\hline $960717-1 / 7 \mathrm{~F}$ & Intestine & $+1-$ & $4 / 9$ & $40,63,105$ & 3 \\
\hline \multicolumn{2}{|c|}{$\begin{array}{l}\text { 'No plasmids } \\
\text { 'E22 received from E. Biosca, } \\
\text { Universidad de Valencia, Spain } \\
\text { '90-2-11 received from E. Myhr, } \\
\text { National Veterinary Institute, } \\
\text { Oslo, Norway }\end{array}$} & \multicolumn{4}{|c|}{$\begin{array}{l}\text { ¿Ö120 }(910527-1 / 2) \text { received } \\
\text { from. U. Johansson, National } \\
\text { Veterinary Institute, Uppsala, } \\
\text { Sweden } \\
\text { ×938 received from R. J. Siebeling, } \\
\text { Louisiana State University, LA, USA }\end{array}$} \\
\hline
\end{tabular}

the ATCC 33149 strain showed reactions typical of biotype 2, i.e. negative for indole production, ornithine decarboxylation, growth at $42^{\circ} \mathrm{C}$ and acid production from mannitol (Tison et al. 1982). The isolates recovered from the first outbreak did not produce acid from mannitol, whereas 11 isolates recovered from the second outbreak were mannitol positive. These 11 isolates were prevalent in both mucus and intestine (Table 1).

Each Vibrio vulnificus isolate was tested against 16 antibacterial drugs and they showed resistance to polymyxin B only. However, a few of the strains from each outbreak showed intermediate resistance to cephal. othin, erythromycin, neomycin, penicillin and streptomycin. Strain Ö120 isolated from a diseased eel in Sweden was the only strain that exhibited resistance to tetracycline.

\section{Serology}

The Vibrio vulnificus isolates recovered from the first outbreak were serologically homogenous. Each isolate expressed capsule type 9 and belonged to LPS serovar O4 (Table 1). Nine of the 20 isolates from the second outbreak were serological identical to those from the first outbreak. One isolate expressed capsule type 9 and a non-typeable LPS type. The remaining 10 isolates were non-typeable in either capsular or LPS serological reagents. The biotype 2 reference strain ATCC 33149, the Spanish strain E22, which has been reported to belong to serovar E (Biosca et al. 1997a), and the 3 other eel virulent reference strains belonged to the $\mathrm{O} 4$ serovar and had capsule type 9 .

\section{Plasmid analysis and ribotyping}

the $V$. vulnificus specific DNA probe directed against the cytolysin gene (Wright et al. 1993). Each of the 32 isolates recovered from the 2 outbreaks differed phenotypically from the description of $V$. vulnificus biotype 2 by Tison et al. (1982) in that they were positive in indole production and showed variable reaction in acid production from mannitol. $V$. vulnificus strains isolated from diseased eels in Spain, Norway and Sweden and
All Vibrio vulnificus isolates examined from the 2 outbreaks contained at least 1 plasmid of high molecular mass. Different plasmid profiles were observed (Table 1, Fig. 1). Each $V$. vulnificus isolate recovered from the first outbreak showed an identical plasmid profile which consisted of 3 plasmids with a size of 40 , 


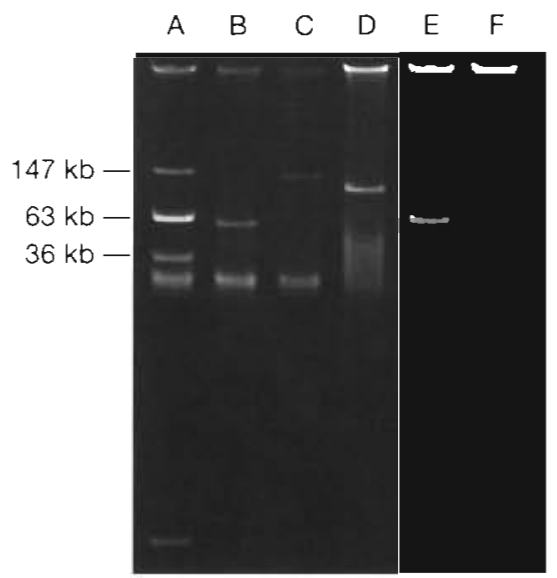

Fig. 1. Vibrio vulnificus. Examples of plasmid profiles of this bacterium isolated from diseased eels. Lanes: A, Escherichia coli 39R 861 (4 plasmids ranging from 147 to $6.9 \mathrm{~kb}$ ); $\mathrm{B}, E$. coli V517 (8 plasmids ranging from 54 to $2.0 \mathrm{~kb}$ ); $\mathrm{C}, 960717-1 / 4 \mathrm{~A}$; D, $960717-1 / 6 \mathrm{C} ; \mathrm{E}, 960717-1 / 5 \mathrm{~B} ; \mathrm{F}, 960717-1 / 2 \mathrm{C}$

63, and $105 \mathrm{~kb}$, respectively. A similar plasmid profile was seen in 5 isolates recovered from the second outbreak. $V$. vulnificus isolated from the second disease outbreak showed 5 different plasmid profiles. Eight isolates contained a $135 \mathrm{~kb}$ size plasmid; 3 isolates contained a $105 \mathrm{~kb}$ plasmid; 3 isolates contained a $63 \mathrm{~kb}$ size plasmid and 1 isolate contained both a 105 and a $135 \mathrm{~kb}$ plasmid. There was no correlation between the tissue source from which $V$. vulnificus was isolated and the plasmid profiles. Nor was there any association between a particular plasmid and tetracyclin resistance found in the Swedish strain (Table 1). From each of 6 of the 7 eels studied in the second outbreak V. vulnificus isolates which showed at least 2 unique plasmid profiles were isolated (Table 1). The reference strain ATCC 33149 and the strain isolated from diseased eel in Spain contained plasmids which were 56 and $67 \mathrm{~kb}$ in size. It should be noted that plasmid sizes are approximate, as the size estimates of large plasmids may vary upon repeated analyses.

Ribotyping of Vibrio vulnificus isolated from the 2 outbreaks produced 2 different HindIII ribotypes (Table 1 , Fig. 2). Each of the 2 ribotypes which differed by 6 DNA fragments showed a total of 14 fragments containing rRNA genes which ranged in size from 1.5 to $8 \mathrm{~kb}$. All isolates from the first outbreak showed an identical ribotype 3 , which was also shown by 9 of 20 isolates recovered from the second outbreak. However, the remaining isolates from the second outbreak showed an identical ribotype $4 . V$. vulnificus isolates from a single eel or from the same source of sample (Table 1) often showed different ribotypes. $V$. vulnificus strains isolated previously from diseased eels in Japan, Spain, Norway and Sweden showed ribotype 3.

\section{Experimental infection}

Vibrio vulnificus isolates which belonged to LPS serovar 04 and capsule type 9 were highly virulent for eels, with moribund fish showing signs of haemorrhagic septicemia. Mortalities were observed 1 to $2 \mathrm{~d}$ following intraperitoneal challenge. There were no obvious differences in mortalities between isolates grown at 20 or $37^{\circ} \mathrm{C}$ before intraperitoneal injection. Preliminary experiments showed that eel passages of the isolates did not change the $\mathrm{LD}_{50}$. Therefore, tests were performed with cultures stored at $-80^{\circ} \mathrm{C}$ without fish passage. Each isolate which expressed LPS serovar $\mathrm{O} 4$ and capsule type 9 was virulent to eels. $\mathrm{LD}_{50}$ doses ranged from $<9.4 \times 10^{3} \mathrm{CFU}_{\text {fish }}{ }^{-1}$ to $2.3 \times$ $10^{5} \mathrm{CFU} \mathrm{fish}^{-1}$. $V$. vulnificus was recovered from dead or moribund eels in pure culture. The isolates with unknown LPS and capsule type were non-virulent for eels ( $>10^{7}$ and $>10^{8} \mathrm{CFU}_{\text {fish }}{ }^{-1}$ ) (Table 2).

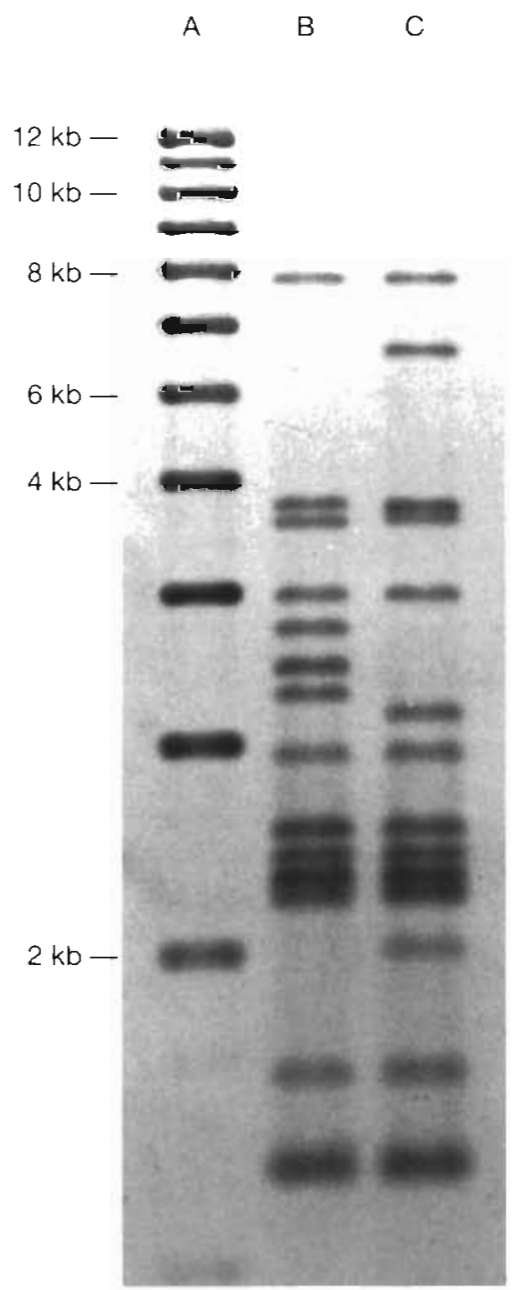

Fig. 2. Vibrio vulnificus. Examples of HindIII ribotypes of this bacterium isolated from diseased eels. Lanes: $A, 1 \mathrm{~kb}$ molecular weight standard $B$, ribotype 3 , C, ribotype 4 
Table 2. Vibrio vulnificus. $50 \%$ lethal dose $\left(L_{50}\right)$ of selected strains for eels

\begin{tabular}{|c|c|c|}
\hline Strain no. & $\mathrm{LD}_{50}\left(\mathrm{CFU}\right.$ fish $\left.^{-1}\right)$ & Plasmid size $(\mathrm{kb})$ \\
\hline \multicolumn{3}{|c|}{ Serovar O4/capsule type 9} \\
\hline $960426-1 / 4 \mathrm{~A}$ & $<9.4 \times 10^{3}$ & $40,63,105$ \\
\hline $960426-1 / 4 C$ & $9.5 \times 10^{3}$ & $40,63,105$ \\
\hline $960717-1 / 2 C$ & $1.9 \times 10^{5}$ & 63 \\
\hline $960717-1 / 2 \mathrm{~F}$ & $2.3 \times 10^{5}$ & $40,63,105$ \\
\hline $960717-1 / 5 \mathrm{~A}$ & $8.8 \times 10^{4}$ & 105 \\
\hline ATCC 33149 & $1.4 \times 10^{4}$ & 56,67 \\
\hline E22 & $4.2 \times 10^{3}$ & 56,67 \\
\hline \multicolumn{3}{|c|}{ Serovar non-typeable } \\
\hline $960717-1 / 3 C$ & $>2.7 \times 10^{7}$ & 105 \\
\hline $960717-1 / 4 \mathrm{~A}$ & $>8.3 \times 10^{8}$ & 135 \\
\hline $960717-1 / 4 \mathrm{~B}$ & $>8.1 \times 10^{8}$ & 135 \\
\hline
\end{tabular}

\section{DISCUSSION}

This report describes recurrent disease outbreaks of Vibrio vulnificus serovar O4 (serovar E) on a Danish eel farm which utilizes brackish water. Lesions and other macroscopic findings on diseased eels were similar to those reported by Biosca et al. (1991). However, in contrast to observations made by Biosca et al. (1991) the most characteristic signs of the disease were observed in the head region, which exhibited weak haemorrhaging to extensive ulcerations often associated with deep muscle necrosis in both the upper and lower jaws.

The biochemical and physiological reactions for the 32 isolates recovered from the 2 outbreaks were very homogeneous for the traits tested, except for acid production from mannitol. Biosca et al. (1996) proposed that indole production was the single biochemical trait which distinguished biotype 1 and biotype 2 (serovar E) phenotypically. Vibrio vulnificus strains isolated from Sweden were reported by Biosca et al. (1997a) to be indole-positive but did not belong to serovar $\mathrm{E}$. All $V$. vulnificus isolates from Danish diseased eels were indole-positive and the virulent isolates belonged to serovar O4 (serovar E), which suggests that indole production may not be a reliable marker to identify strains virulent for eels. $V$. vulnificus isolated from the first outbreak and each serovar O4 isolate recovered from the second outbreak did not produce acid from mannitol. This investigation suggests a negative reaction for acid production from mannitol might be a marker for eel-virulent strains. By contrast Biosca et al. (1996) recovered environmental strains which were negative for acid production from D-mannitol. The present study supports the contention of Arias et al. (1997) that the division of $V$. vulnificus into 2 biotypes based on the phenotypic criteria originally established by Tison et al. (1982) can no longer be sustained and leads to taxonomic confusion.
None of the Danish eel isolates were resistant to oxolinic acid or tetracycline, which were used to treat each of the 2 disease outbreaks. Nor were the nonvirulent isolates from the second outbreak resistant to tetracycline or trimethoprim, which was reported by Amaro et al. (1992a) for environmental strains. Despite absence of antjbiotic resistance, methods other than chemotherapy must be identified to control these epizootics, since treatment with antibiotics has little effect. Amaro et al. (1995) proposed that the use of freshwater or the lowering of the water temperature to below $20^{\circ} \mathrm{C}$ may be good prophylactic measures to control Vibrio vulnificus infections. These authors found the highest mortalities in eels maintained in a water salinity of 0.5 to $1.5 \%$, whereas no mortalities were detected when eels were farmed in freshwater (Amaro et al. 1995). On the Danish eel farm, the water salinity was $0.9 \%$ during the disease outbreaks and the mortalities continued into the following year. When eels were introduced into freshwater, in some sections of the farm, there was a reduction in eel mortality. If farmers are to profit from the rearing of eels in brackish water, efforts are needed to investigate the efficacy of vaccination against $V$. vulnificus.

Little is known about the ecology of the eel pathogenic serovar in the aquatic environment. Recently, strains of Vibrio vulnificus, referred to as biotype 2 strains, were isolated at low frequencies from sediment and brackish water samples (Høi et al. 1998). The occurrence of biotype 2 in Danish marine environments may have been underestimated, since indole production was used to distinguish the 2 biotypes. Biosca et al. (1997b) detected $V$. vulnificus serovar $E$ (biotype 2) in both infected and asymptomatic eels, which suggests that eels can also serve as a reservoir for this pathogen. The presence in the Danish eel farm examined of both virulent and non-virulent isolates of $V$. vulnificus in the kidney, mucus, spleen, gills and intestines seems to indicate that this organism is closely associated with eels.

The sources for Vibrio vulnificus in disease outbreaks are: (1) brackish water introduced into the eel farm; (2) newly purchased elvers transferred directly to the production unit; and (3) introduction of wild eels captured in Danish coastal waters. In 1997, following introduction of wild eels, another eel farm experienced a severe disease outbreak caused by $V$. vulnificus which exhibited LPS serovar O4 and capsule type 9 (authors' unpubl. data).

A serotyping system based on monoclonal antibodies to the O side chain of LPS (Martin \& Siebeling 1991) and polyclonal capsule antisera (Simonson \& Siebeling 1993) recognized serologically most isolates of Vibrio vulnificus recovered from diseased eels. A group of non-typeable isolates may represent environmental 
strains with little or no pathogenic significance. Capsule type 9 was detected in all isolates belonging to the O4 serovar. This suggests a linkage between the expression of this particular $O$ antigen and capsule type. The results of this study indicate that the presence of capsule type 9 and LPS O4 discriminates the eel-virulent strains from non-virulent strains. One isolate had a capsule type 9 without belonging to the $\mathrm{O} 4$ serovar; this isolate showed the ribotype 4 profile which was found among the non-virulent isolates. It has been shown that the capsule may not be necessary for eel virulence when cells are injected intraperitoneally (Biosca et al. 1993). However, a capsule seems to be essential for waterborne infectivity (Amaro et al. 1995). It is likely that the capsule increases the pathogenic potential for eels of serovar $\mathrm{E}$ (serovar O4), facilitating initial mucusal adherence (Amaro et al. 1995). Additional studies on the serology of $V$. vulnificus are required to obtain an overall view on the antigenic diversity of the species. Finally, we conclude that the strains of $V$. vulnificus belonging to serovar $\mathrm{O} 4$ and capsule type 9 , serologically identical to the original Japanese isolate and the Spanish serovar $E$, were the agents responsible for the 2 disease outbreaks that occurred on the Danish eel farm.

Høi et al. (1997) reported that ribotype profile can be used to distinguish biotype 1 and biotype 2 isolates. Serovar $\mathrm{O} 4$ and capsule type 9 isolates were pathogenic for eels and exhibited the ribotype 3 profile. In addition, eel virulent strains from Spain, Japan, Norway and Sweden exhibited the same properties. Ribotype 3 was similar to the ribotype for serovar $E$ reported by Biosca et al. (1997a). Virulent Vibrio vulnificus isolates from each of the 2 disease outbreaks showed the same serotype and ribotype profile, indicating that $V$. vulnificus survived in the eels or in the environment between the 2 outbreaks.

All Vibrio vulnificus isolates recovered from the first outbreak harboured 3 plasmids and expressed serovar O4 and capsule type 9, whereas isolates recovered from the second outbreak, while expressing $O 4$ and capsule type 9, exhibited different plasmid profiles. Some isolates harboured 3 plasmids, whereas other isolates harboured only 1 plasmid which was either approximately 63 or $105 \mathrm{~kb}$ in size. Our findings are in contrast to those of Biosca et al. (1993), which showed 4 out of 5 biotype 2 (serovar E) strains harbouring 2 plasmids, including a common plasmid approximately $72 \mathrm{~kb}$ in size.

The lethality assays revealed that Vibrio vulnificus serovar O4 was highly virulent for eels, while serologically non-typeable isolates proved non-virulent for eels. The LPS characteristics on a bacterial surface are correlated with pathogenicity for eels, and according to Amaro \& Biosca (1996) only those belonging to serovar $\mathrm{E}$ can colonize and develop infection in eels. Biosca et al. (1996) found that serovar E strains were virulent for eels ( $L D_{50}$ ranging from $1.6 \times 10^{1}$ to $5.5 \times$ $10^{5} \mathrm{CFU}$ fish ${ }^{-1}$ ) and neither environmental nor human. clinical biotype 1 isolates were virulent for eels $\left(>10^{7}\right.$ and $10^{8} \mathrm{CFU}$ fish ${ }^{-1}$, respectively). The virulence results reported in this study confirmed the work of Biosca et al. (1996) in that all serovar O4 (serovar E) isolates were virulent for eels whereas the serologically nontypeable isolates were non-virulent (Table 2). A relationship between presence of certain plasmids and eel virulence was not established.

Wound infections have been related to the handling of eels or fishing in Denmark (Dalsgaard et al. 1996b). But to the authors' knowledge no Danish eel farmers have so far been infected with Vibrio vulnificus. All $V$. vulnificus serovars should be regarded as opportunistic human pathogens, and therefore eel farmers in contact with brackish water and contaminated material such as eels should be alert to the risk of acquiring infection.

Acknowledgements. The technical assistance of Anita Forslund, Kirsten Kaas, and Charlotte Wittchen is highly appreciated. This work received financial support from The Ministry of Food, Agriculture and Fisheries, The Danish Environmental Protection Agency, and The Elisabeth and Knud Petersens Foundation. L.H. was supported by a fellowship from The Royal Veterinary and Agricultural University. Preparation of serological reagents was supported by the Louisiana Sea Grant College Program, a part of the National College Program maintained by NOAA, U.S. Department of Commerce

\section{LITERATURE CITED}

Amaro C, Biosca EG (1996) Vibrio vulnificus biotype 2, pathogenic for eels, is also an opportunistic pathogen for humans. Appl Environ Microbiol 62:1454-1457

Amaro C, Biosca EG, Esteve C, Fouz B, Toranzo AE (1992a) Comparative study of phenotypic and virulence properties in Vibrio vulnificus biotypes 1 and 2 obtained from a European eel farm experiencing mortalities. Dis Aquat Org $13: 29-35$

Amaro C, Biosca EG, Fouz B, Garay E (1992b) Electrophoretic analysis of heterogeneous lipopolysaccharides from various strains of Vibrio vulnificus biotypes 1 and 2 by silver staining and immunoblotting. Curr Microbiol 25:99-104

Amaro C, Biosca EG, Fouz B, Alcaide E, Esteve C (1995) Evidence that water transmits Vibrio vulnificus biotype 2 infections to eels. A.ppl Environ Microbiol 61:1133-1137

Amaro C, Fouz B, Biosca EG, Marco-Noales E, Collado R (1997) The lipopolysaccharide O side chain of Vibrio vulnificus serogroup $E$ is a virulence determinant for eels Infect Immun 65:2475-2479

Arias CR, Verdonck L, Swings J, Aznar R, Garay E (1997) A polyphasic approach to study the intraspecific diversity amongst Vibrio vulnificus isolates. Syst Appl Microbiol 20: 622-633

Barrow GI, Feltham RKA (eds) (1993) Cowan and Steel's manual for the identification of medical bacteria, 3rd edn Cambridge University Press, Cambridge 
Biosca EG, Amaro C, Esteve C, Alcaide E, Garay E (1991) First record of Vibrio vulnificus biotype 2 from diseased European eel, Anguilla anguilla L. J Fish Dis 14:103-109

Biosca EG, Llorens H. Garay E, Amaro C (1993) Presence of a capsule in Vibrio vulnificus biotype 2 and its relationship to virulence for eels. Infect Immun 61:1611-1618

Biosca EG, Oliver JD, Amaro C (1996) Phenotypic characterization of Vibrio vulnificus biotype 2, a lipopolysaccharidebased homogeneous $O$ serogroup within Vibrio vulnificus. Appl Environ Microbiol 62:918-927

Biosca EG, Amaro C, Larsen JL, Pedersen K (1997a) Phenotypic and genotypic characterization of Vibrio vulnificus: proposal for the substitution of the subspecific taxon biotype for serovar. Appl Environ Microbiol 63:1460-1466

Biosca EG, Marco-Noales E, Amaro C, Alcaide E (1997b) An enzyme-linked immunosorbent assay for detection of Vibrio vulnificus biotype 2: development and field studies. Appl Environ Microbiol 63:537-542

Dalsgaard A, Mortensen HF, Mølbak K, Dias F, Serichantalergs O, Echeverria P (1996a) Molecular characterization of Vibrio cholerae O1 strains isolated during cholera outbreaks in Guinea-Bissau. J Clin Microbiol 34:1189-1192

Dalsgaard A, Møller NF, Bruun B, Høi L, Larsen JL (1996b) Clinical manifestations and epidemiology of Vibrio vulnificus infections in Denmark. Eur J Clin Microbiol Infect Dis 15:227-232

Høi L, Dalsgaard A, Larsen JL, Warner JM, Oliver JD (1997) Comparison of ribotyping and randomly amplified polymorphic DNA PCR for characterization of Vibrio vulnificus. Appl Environ Microbiol 63:1674-1678

Høi L, Larsen JL, Dalsgaard I, Dalsgaard A (1998) Occurrence of Vibrio vulnificus biotypes in Danish marine environments. Appl Environ Microbiol 64:7-13

Kelly MT, Hickman-Brenner FW, Farmer JJ III (1991) Vibrio. In: Balows $\mathrm{A}$, Hausler WJ, Hermann $\mathrm{KL}$, Isenberg $\mathrm{HD}$, Shadomy HJ (eds) Manual of clinical microbiology. ASM Press, Washington, DC, p 384-395

Martin SJ, Siebeling RJ (1991) Ydentification of Vibrio vulnificus $\mathrm{O}$ serovars with antilipopolysaccharide monoclonal antibody. J Clin Microbiol 29:1684-1688

Mellergaard S, Dalsgaard I (1987) Disease problems in Danish eel farms. Aquaculture 67:139-146

Muroga K, Jo Y, Nishibuchi M (1976) Pathogenic Vibrio iso-

Editorial responsibility: David Bruno,

Aberdeen, Scotland, UK lated from cultured eels. I. Characteristics and taxonomic status. Fish Pathol 11:141-145

Oliver JD (1989) V'ibrio vulnificus. In: Doyle MP (ed) Foodborne bacterial pathogens. Marcel Dekker, Inc, New York, p $569-600$

Olsen JE (1990) An improved method for rapid isolation of plasmid DNA from wild-type gram-negative bacteria for plasmid restriction profile analysis. Lett Appl Microbiol 10:209-212

O'Neill KR, Jones SH, Grimes DJ (1992) Seasonal incidence of Vibrio vulnificus in the Great Bay estuary of New Hampshire and Maine. Appl Environ Microbiol 58:3257-3262

Pedersen K, Larsen JL (1993) rRNA gene restriction patterns of Vibrio anguillarum serogroup 01 . Dis Aquat Org 16: $121-126$

Reed MJ, Müench M (1938) A simple method for estimating fifty percent endpoints. Am J Hyg 27:493-497

Rorhelle PA, Fry JC, Day MJ, Bale MJ (1985) An accurate method for estimating sizes of small and large plasmids and DNA fragments by gel electrophoresis. J Gen Appl Microbiol 132:53-59

Simonson JG, Siebeling RJ (1986) Rapid serological identification of Vibrio vulnificus by anti-H coagglutination. Appl Environ Microbiol 52:1299-1304

Simonson JG, Siebeling RJ (1993) Immunogenicity of Vibrio vulnificus capsular polysaccharides and polysaccharideprotein conjugates. Infect Immun 61:2053-2058

Threlfall EJ, Rowe B, Ferguson JL, Ward LR (1986) Characterization of plasmids conferring resistance to gentamycin and apramycin in strains of Salmonella typhimurium phage type 204c isolated in Britain. J Hyg 97:419-426

Tison DL, Nishibuchi M, Greenwood JD, Seidler RJ (1982) Vibrio vulnificus biogroup 2; new biogroup pathogenic for eels. Appl Environ Microbiol 44:640-646

Veenstra J, Rietra JPGM, Stoutenbeek CP, Coster JM, De Hier HHW, Dirskgo S (1992) Infection by an indol-negative variant of Vibrio vulnificus transmitted by eel. J Infect Dis 16:209-210

Wright AC, Miceli GA, Landry WL, Christy JB, Watkins WD, Morris JG Jr (1993) Rapid identification of Vibrio vulnificus on nonselective media with an alkaline phosphataselabeled oligonucleotide probe. Appl Environ Microbiol 59: $541-546$

Submitted: August 7, 1998; Accepted: November 2, 1998 Proofs received from author(s): February 3, 1999 